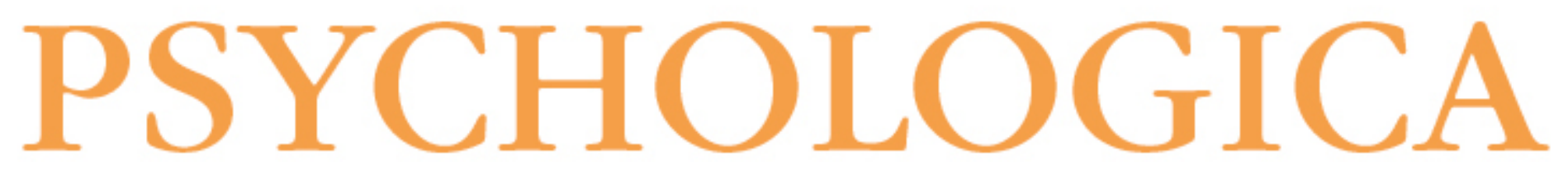

\title{
Emotional dysregulation as a predictor of peer attachment perceptions of adolescents in residential care
}

Autor(es): $\quad$ Lino, Alexandra M.; Lima, Luiza Nobre

Publicado por: Imprensa da Universidade de Coimbra

URL

persistente: $\quad$ URI:http://hdl.handle.net/10316.2/42363

DOI: $\quad$ DOI:https://doi.org/10.14195/1647-8606_60-1_4

Accessed : $\quad$ 26-Apr-2023 14:22:32

A navegação consulta e descarregamento dos títulos inseridos nas Bibliotecas Digitais UC Digitalis, UC Pombalina e UC Impactum, pressupõem a aceitação plena e sem reservas dos Termos e Condições de Uso destas Bibliotecas Digitais, disponíveis em https://digitalis.uc.pt/pt-pt/termos.

Conforme exposto nos referidos Termos e Condições de Uso, o descarregamento de títulos de acesso restrito requer uma licença válida de autorização devendo o utilizador aceder ao(s) documento(s) a partir de um endereço de IP da instituição detentora da supramencionada licença.

Ao utilizador é apenas permitido o descarregamento para uso pessoal, pelo que o emprego do(s) título(s) descarregado(s) para outro fim, designadamente comercial, carece de autorização do respetivo autor ou editor da obra.

Na medida em que todas as obras da UC Digitalis se encontram protegidas pelo Código do Direito de Autor e Direitos Conexos e demais legislação aplicável, toda a cópia, parcial ou total, deste documento, nos casos em que é legalmente admitida, deverá conter ou fazer-se acompanhar por este aviso.

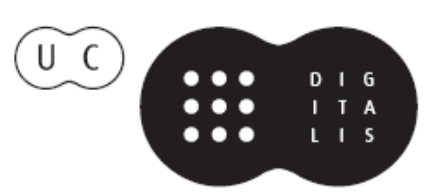


vOLUME
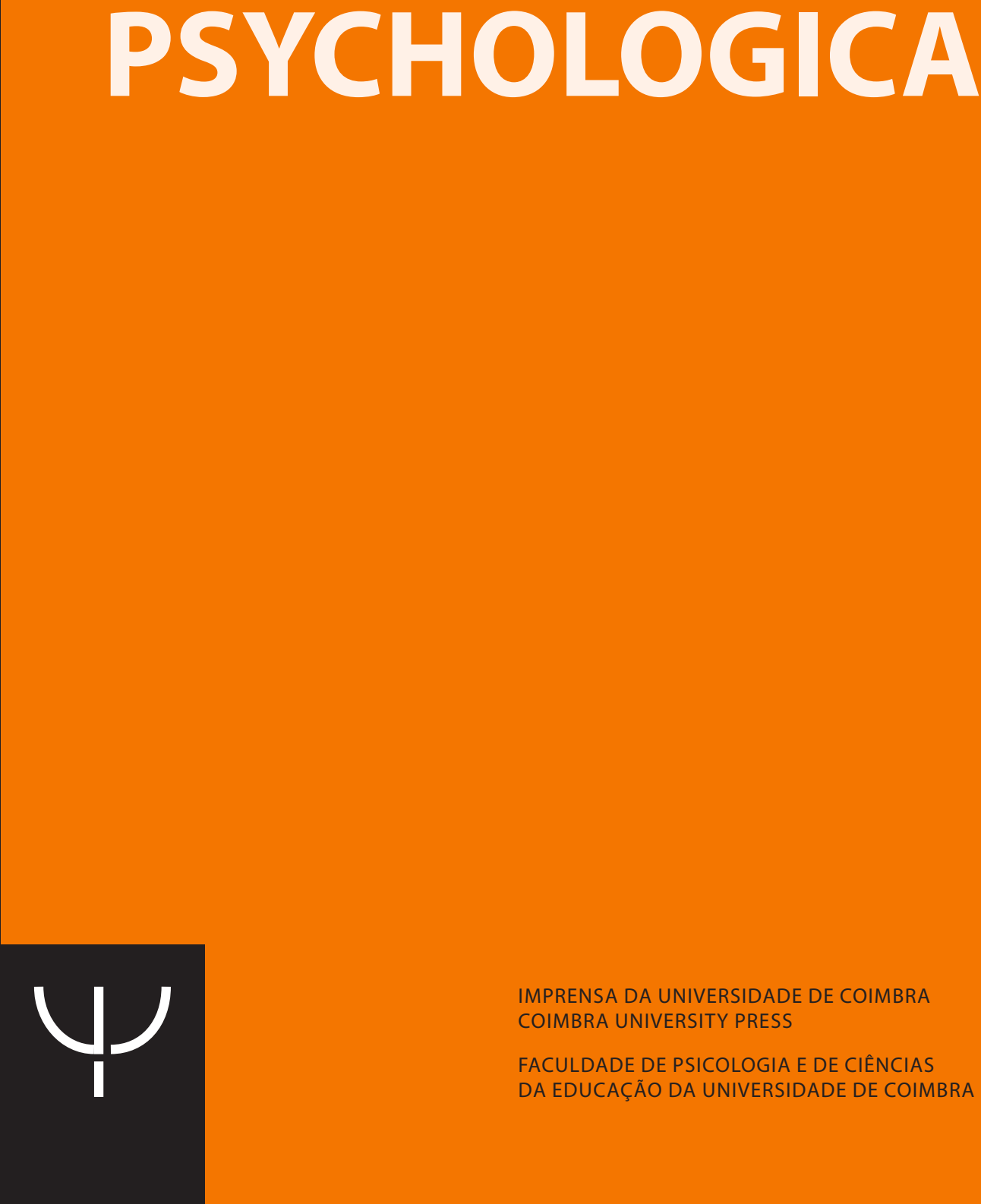

IMPRENSA DA UNIVERSIDADE DE COIMBRA

COIMBRA UNIVERSITY PRESS

FACULDADE DE PSICOLOGIA E DE CIÊNCIAS

DA EDUCAÇÃO DA UNIVERSIDADE DE COIMBRA 


\title{
Emotional dysregulation as a predictor of peer attachment perceptions of adolescents in residential care
}

\author{
Alexandra M. Lino e Luiza Nobre Lima ${ }^{2}$
}

\begin{abstract}
Adolescents who live in residential care tend to have a development characterized by insecure and ambivalent emotional experiences. In addition, they frequently exhibit levels of emotional dysregulation that potentially compromise the quality of their interpersonal relationships. Considering that in this context the peer group has an important role in providing emotional support, the present study aimed to analyse the levels of emotional dysregulation of adolescents living in residential care and to explore its predictive role in the perception of the attachment to peers. The sample is composed of 100 adolescents (71 girls; 29 boys) living in residential care, aged between 12-18 years old. Measures included the Portuguese versions of the Abbreviated Dysregulation Inventory and the Inventory of Parent and Peer Attachment (peer version only). The levels of dysregulation were not high, and adolescents displayed a higher affective than a behavioural dysregulation. Only cognitive dysregulation negatively accounted for the variability of communication, trust and perception of attachment to peers in general. This is understandable, since cognition has an important role in managing negative emotions and controlling their behavioural outputs. Albeit modest, the results encourage the promotion of emotional regulation as a means of fostering secure interpersonal relationships in residential care.
\end{abstract}

Keywords: adolescents; residential care; emotional dysregulation; peer attachment

1 Faculty of Psychology and Education Sciences. E-mail: alexandra.imlino@gmail.com

2 Cognitive and Behavioral Center for Research and Intervention (R\&D Unit). Faculty of Psychology and Education Sciences. E-mail: luizabelima@fpce.uc.pt

Artigo recebido a 25-06-2016 e aprovado a 16-02-2017. 
A desregulação emocional como preditora da perceção de vinculação aos pares de adolescentes em acolhimento residencial

\section{Resumo}

Adolescentes em acolhimento residencial tendem a ter um desenvolvimento marcado por experiências de grande insegurança e ambivalência afetiva, exibindo com frequência níveis de desregulação emocional que comprometem a qualidade das suas relações interpessoais. Considerando que neste contexto o grupo de pares assume um papel de grande suporte emocional, este estudo procurou analisar os níveis de desregulação emocional de adolescentes acolhidos e o seu papel preditor na perceção da vinculação aos pares. Foi recolhida uma amostra de 100 adolescentes (71 raparigas; 29 rapazes) em acolhimento residencial, com idades entre os 12 e os 18 anos. Como instrumentos foram utilizados o Inventário de Desregulação Abreviado e o Inventário de Vinculação na Adolescência (versão para pares). Os níveis de desregulação reportados foram baixos, verificando-se uma maior desregulação afetiva do que comportamental. A desregulação cognitiva é a única que explica, negativamente, a variância da comunicação, da confiança e da perceção global de vinculação aos pares. A explicação pode residir no papel regulador que a cognição desempenha na gestão das emoções negativas e no controlo da sua expressão comportamental. Ainda que modestos, os resultados encorajam o investimento na promoção da regulação emocional dos adolescentes em acolhimento residencial, com vista ao estabelecimento de relações interpessoais seguras.

Palavras-chave: adolescentes; acolhimento residencial; desregulação emocional; vinculação aos pares

\section{INTRODUCTION}

During adolescence, the peer group plays a major role in the social and emotional development of the individual (Gorrese \& Ruggieri, 2012). Indeed, the peer group is an especially rich environment for adolescents to try out different identities and practice different ways of thinking that will shape their identity (Meeus, Iedema, Maassen, \& Engels, 2005). Also in this context they begin to establish intimate and romantic relationships that prepare them for adult intimacy (Jongenelen, Carvalho, Mendes, \& Soares, 2009). As such, peer relationships are often considered as having a modulating role on the adolescents' emotional experiences. In fact, adolescents resort to peers as valuable resources of information on how to respond to social or emotional situations 
(Steinberg \& Silk, 2002) or how to handle pressing issues like sexuality, independence and intimacy (Morris, Silk, Steinberg, Myers, \& Robinson, 2007).

In early adolescence, peers are considered to be social influences to deter antisocial behaviour, even though this influence seems to decrease by middle adolescence (Cook, Buehler, \& Henson, 2009). An open communication with peers has also proven to provide a better satisfaction with life and to decrease negative health symptoms (Tomé, Gaspar de Matos, Camacho, Simões, \& Diniz, 2012). In a recent systematic review, Boruah (2016) concluded that peer pressure can have a positive impact in the development of healthy and constructive behaviours (e.g., involvement in physical activities, healthy eating behaviours), in academic motivation and outcomes, and in healthy social and emotional development.

In fact, studies on the importance of peer relationships in adolescence showed that peer attachment is positively associated with the adolescents' self-esteem and psychological well-being (e.g., Balluerka, Gorostiaga, Alonso-Arbiol, \& Aritzeta, 2016; Gorrese \& Ruggieri, 2012; Sasikala \& Cecil, 2016). Secure attachment relationships with peers promote emotional awareness, empathy, and positive expressiveness, thus fostering appropriate social behaviours (Laible, 2007). Also, by providing a context for acquiring new experiences and to form new relationships, the peer group offers new opportunities to re-evaluate insecure relationships established early on, and to build new internal models (Soares, 1996).

For an adolescent living and growing up in residential care the peer group has a particularly relevant value. By ensuring the presence of someone to whom they can confide their most intimate thoughts (Nobre-Lima, 2009), the peer group often comes to replace immediate relatives and adult influence, assuring emotional support and a sense of self-worth and status (Shaw, 2014). After all, peers are "often the only 'chosen' and free relationships" adolescents have in residential care (Emond, 2014, p. 200). In a residential setting, the peer group can also act as an important resource for learning and stimulation (Emond, 2003; Morgan, 2009; Nobre-Lima, 2009).

Unfortunately, the vast majority of adolescents living in residential group homes had a childhood characterized by experiences of abuse and/or neglect, to which is added, in many other cases, several unsuccessful placement experiences (Shaw \& Frost, 2013). As a result of the traumatic events experienced throughout their development, adolescents in residential care are likely to present several deficits in their ability to cope with stressful stimuli and to regulate their emotions (Cook et al., 2005; Kim \& Cicchetti, 2010; Silberg, 2013).

From a psychological point of view, emotional regulation can be understood as a coping mechanism that promotes the intellectual growth of the individual (Lazarus, 2006). Biologically, this process represents an increase of complexity of the maturing brain systems that adaptively regulate the interaction between the 
developing organism and the social environment (Schore, 2001). On the contrary, emotional dysregulation refers to dysfunctional operations in the process of emotional regulation (Cole, Martin, \& Dennis, 2004). It is characterized by difficulties in assimilating and managing emotional experiences, especially the ones that create stress and anxiety. Emotional dysregulation makes the individual more prone to psychopathology (Schore, 2001) and impairs the development of the necessary capacities to maintain healthy interpersonal relationships (Schore, 2003).

As shown by Greger, Myhre, Lydersen, and Jozefiak (2015), youth in residential care show a high prevalence of emotional and behavioural disorders, with an increased probability of both co-occurring. As a consequence, the quality of the relationships they establish with peers is highly compromised (Cicchetti \& Toth, 2005; Trickett, Negriff, Ji, \& Peckins, 2011). In fact, adolescents in residential care reveal poor quality of life in domains such as friendship and school relationships (Greger, Myhre, Lydersen, \& Jozefiak, 2016).

Gwynn, Meyer and Schaefer (1993) have long stated that many of the adolescents placed in group homes typically suffer from significant social skills deficits, overaggressive and antisocial behaviours, fears of groups, distortions in reality assessment, hyperactivity, impulsiveness and other ego weaknesses. These same behaviours and difficulties are often the reason why peer violence in residential care has become so recurrent (Barter, 2003, 2008; Monks, Smith, Naylor, Ireland, \& Coyne, 2009). However, it is important to consider that many of the aggressive or hostile behaviours displayed by these adolescents are, in fact, the reflection of underlying maladaptive expressions of a desire for proximity and acceptance, since these behaviours have been the only example of "affection" they know (Crittenden, 1992).

Despite the emotional and behavioural difficulties, for adolescents in residential care the proximity to the peer group allows them to express their ideas and feelings, to develop empathy and to be positively involved in the relationship with others (Mota \& Matos, 2010, 2015). According to these same authors, this will help to improve social skills that can protect their development. As already shown by Bolger, Patterson and Kupersmidt (1998), establishing positive relationships with peers can help buffering the negative consequences of maltreatment that occurred over the child's development. For adolescents living in residential care the perception of attachment to peers has also proved to be an important predictor of their resilience (Inácio, 2015).

As previously demonstrated, in residential care settings peer relationships serve multiple functions in the adaptation process of the cared adolescents. Therefore, promoting the best relationships between peers - which seem to be a valuable resource during and after leaving care - is an important contribution to the social capital of these adolescents (Avery \& Freundlich, 2009; Barn, 2010; Manful \& Badu-Nyarko, 2014). In order to have a better understanding of the factors that might hinder the 
development of positive and supportive relationships between peers in residential care settings, the main purpose of the present study is, first, to analyse the levels of emotional dysregulation and peer attachment of adolescents living in group homes. Additionally, the current study aims to explore the way through which emotional dysregulation predicts the adolescents' perception of their attachment to peers. We hypothesize that adolescents in residential care display high levels of emotional dysregulation and a perception of poor attachment to peers. We also expect that emotional dysregulation negatively predicts attachment to peers.

\section{METHOD}

\section{Participants}

This sample is composed of 100 adolescents (71 girls and 29 boys), aged between 12 and 18 years old $(\mathrm{M}=14.75$; $\mathrm{DP}=1.88)$, living in eight Infant and Juvenile group homes under the protection measure of extended placement in residential care. In this sample, $35 \%$ of adolescents had already been institutionalized before and more than a half (59\%) are in the current group home for less than 36 months.

\section{Measures}

Emotional dysregulation was assessed using the Abbreviated Dysregulation Inventory (ADI; Mezzich, Tarter, Giancola \& Kirisci, 2001; Portuguese version translated by Petiz \& Rijo, n.d., cited in Petiz, 2011). ADI is a 30-item self-report questionnaire designed to measure three types of psychological dysregulation: Behavioural dysregulation (9 items) referring to behaviour impulsiveness, cognitive dysregulation (10 items) that represents executive cognitive dysfunction, and affective dysregulation (11 items) that refers to emotional lability. Participants responded to items using a four-point Likert type of scale ranging from 0 ("never true") to 3 ("always true"). Higher scores mean more dysregulation, except for the cognitive dysregulation subscale, as the items are inversely scored. When adapted for Portuguese adolescents, the ADI revealed good adjustment indices supporting the final model of three factors $\left(\chi^{2}(400)=1104.513, p<.001 ; \chi^{2} / d f=2.76\right.$; CFI $=$ $.954 ;$ TLI $=.950 ;$ RMSEA $=.054$ with $\mathrm{P}[\mathrm{RMSEA} \leq 0.05]=.052)$, displaying also 
high internal consistency values ( $\alpha=.87$ for behavioural dysregulation; $\alpha=.88$ for cognitive dysregulation; $\alpha=.85$ for affective dysregulation) and temporal stability over a four-week interval, which corroborates its adequate reliability (Motta, Rijo, Sousa, Pereira, \& Correia, n.d.). The same conclusion can be drawn for the present sample, given that Cronbach's a coefficients for the subscales were $.82, .83$ and .86 for behavioural, cognitive and affective dysregulation, respectively. The score for each subscale was calculated based on the average score of the corresponding items.

The Inventory of Parent and Peer Attachment (IPPA; Armsden \& Greenberg, 1987; Portuguese version Neves, 1995) was used to assess peer attachment. This scale measures separately the adolescent's quality of attachment to their mother, father and friends, which together explain $77.32 \%$ of the total variance of the attachment of the adolescent. In the Portuguese adaptation, the three versions presented respectively, .92, .95 and .93 of internal consistency (Neves, Soares, \& Silva, 1999). In the present study, adolescents only answered to the friends scale. This scale consists of 25 items that encompass three factors: Communication (extension and quality of verbal communication), trust (mutual understanding, respect and trust) and alienation (feelings of alienation and isolation towards friends). Participants responded to the items on a five-point Likert scale, ranging from 1 ("never or almost never") to 5 ("always or almost always"). In the present study, the internal consistency assessed by Chronbach's a coefficient was good for the global scale $(\alpha=.88)$ and for the Communication $(\alpha=.82)$ and Trust $(\alpha=.87)$ subscales and low $(\alpha=.55)$ for the Alienation subscale. Since the internal consistency value for the Alienation subscale does not meet criteria for acceptance, this subscale was excluded from further data analysis. The final scores and those for each dimension were calculated based on the average score of the corresponding items.

In order to better characterize the sample, the adolescents answered a brief socio-demographic questionnaire, containing questions regarding age, gender, number of placements, age of first placement and date of arrival at the present residential group home.

\section{Procedures}

Since the institutions have the legal guardianship of the under-aged adolescents of the sample, an authorization request was previously presented to the institutions' boards, in which information about the research and its goals was provided. After the approval, the adolescents were invited to participate in the study. After explaining the aim of the study to the adolescents, they voluntarily accepted to participate on it. All ethical procedures were followed, including anonymity and confidentiality. Visits were scheduled to each institution in order to collect the data. The protocol was 
applied both individually and in group (no more than five elements per turn), according to the availability of the adolescents, their difficulties in verbal comprehension and vocabulary knowledge. Given the characteristics of the sample, we first sought to foster some kind of relationship with the adolescents, in order to involve them in the process. Adolescents with severe cognitive deficits did not participate in the study.

\section{Data analysis}

All analyses were performed using SPSS (v. 23, IBM SPSS). In the present study, only data concerning the total sample were used. Chronbach's a coefficients obtained in the present study for each measure were interpreted according to Hair, Black, Babin, and Anderson (2009). Also, a probability of a type I error of .05 was considered for all analysis. The values of skewness and kurtosis aren't far apart from the ones considered satisfactory for the assumption of normality (Kline, 2011), with values of sk $<3$ and $\mathrm{ku}<8$. The levels of emotional dysregulation and peer attachment were analysed using descriptive statistics, and compared through a paired-samples $t$-test. The effect sizes were interpreted according to Cohen's classification (Cohen, 2008). Since the two measures used do not establish a cut-off point to rigorously classify the levels of emotional dysregulation and perception of attachment to peers, qualitatively analyses were conducted to determine these levels. For the qualitative analyses the means obtained were reduced to the classification scale of the items and compared with the different points of the scale. The higher the means, the more the adolescents tend to be dysregulated and to present a perception of good attachment to their peers. To understand whether the perception of attachment to peers could be predicted by emotional dysregulation, we conducted multiple linear regression analyses with behavioural, cognitive and affective dysregulation as predictors, and attachment to peers, communication and trust as criteria.

\section{RESULTS}

\section{Descriptive analyses of emotional dysregulation and peer attachment}

Means obtained in emotional dysregulation have been reduced to the classification scale of the items (ranging between 0 and 3 points), and a qualitative 
analysis of the results (cf. Table 1) has been performed. The adolescents' answers to the behavioural subscale are very close to "Sometimes True", suggesting that only sometimes they acknowledge themselves as having no control over their behaviour. Similarly, results show that adolescents only perceive lack of control in cognitive and affective dysregulation "sometimes". When considering the discrepancy between the mean value of each dimension of dysregulation, data show a significant difference only between behavioural and affective dysregulation $(t=-4.84 ; p=.000)$, suggesting that adolescents are more affectively than behaviourally dysregulated.

Table 1

Means and Standard Deviations of Emotional Dysregulation, Peer Attachment and Related Comparisons in the Total Sample $(n=100)$

Variables

$\mathrm{M}$

SD

Emotional Dysregulation

Behavioural Dysregulation

.99

.62

Cognitive Dysregulation

1.10

.62

Affective Dysregulation

1.27

.67

Peer Attachment

Communication

3.50

.79

Trust

Global scale

3.66

.61

The same procedure was used in order to analyse the adolescents' attachment to peers (cf. Table 1), with the items ranging between 1 and 5. Results for the global scale revealed that the adolescents' answers indicate they perceive themselves as being attached to peers quite "often" (4), suggesting a good perception of attachment to peers. The same conclusion can be drawn for communication and trust, with the adolescents' answers suggesting that their communication and trust in peers is satisfactory. Statistical comparison of means revealed significant differences between communication and trust $(t=-3.83 ; p=.000)$, as well as between communication and global attachment to peers $(t=-3.75 ; p=.000)$, suggesting that the adolescents' perception of their friends as trustful and of their attachment to them is stronger than their perception of a good communication between them. In light of these results, our first hypothesis was not confirmed. Contrary to what we expected, adolescents in residential care tend to display low levels of emotional dysregulation and perceived their attachment to peers as being good. 


\section{Associations between emotional dysregulation and peer attachment}

As represented in Table 2, results showed that cognitive dysregulation is the only one that correlates with global peer attachment, though moderately. Cognitive dysregulation also revealed a moderate correlation with communication, and a weak one with trust. Results also suggest that a higher cognitive dysregulation of the adolescents is associated with a lower perception of communication, trust and global attachment to peers.

Strong correlations were also found between behavioural and affective dysregulation, as well as between communication and trust, and communication and global attachment. This suggests the way in which these variables are interconnected in the adolescents' development.

Table 2

Inter-Correlations between Emotional Dysregulation and Peer Attachment in Total Sample $(n=100)$

$\begin{array}{llllllll}\text { Variables } & 1 & 2 & 3 & 4 & 5 & 6\end{array}$

Emotional Dysregulation

1. Behavioural

2. Cognitive .091

3. Affective $.627^{\star *}-.039$

Peer Attachment

4. Communication

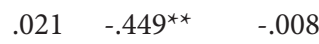

5. Trust $\begin{array}{llll}-.041 & -.254^{*} \quad-.116 \quad .768^{* *}\end{array}$

6. Global scale $-.092-.305^{\star *}$ $-.161$ $.866^{\star *} \quad .931^{\star *}$

${ }^{*} p<.05 ;{ }^{* *} p<.01$

Upon the analysis of the predictive effect of emotional dysregulation on peer attachment (cf. Table 3), results showed that the general model composed of behavioural, cognitive and affective dysregulation significantly predicts the perception adolescents in residential care have of their attachment to peers $(p<.05)$, explaining $12.6 \%$ of its variability in the total scale, $21.2 \%$ of communication with peers, and $8.7 \%$ of perceived trust. Similar to previous results, cognitive dysregulation stood out once again as the dimension that best accounts for the variability in perceived attachment to peers, in the total scale and in communication and trust. This means that the higher the cognitive dysregulation, the lower is the adolescents' communication and trust in peers, as well as their perception of attachment to them. 
Therefore, our second hypothesis was confirmed since emotional dysregulation predicted attachment to peers. Nonetheless, cognitive dysregulation is the type of psychological dysregulation that best explains attachment to peers.

Table 3

Multiple Regression Analysis of Emotional Dysregulation in the Prediction of Peer Attachment $(n=100)$

\begin{tabular}{lcccccc}
\hline \multicolumn{1}{c}{ Predictors } & $\mathrm{R}$ & $\mathrm{R}^{2}$ & $\mathrm{R}^{2}$ adj & $F$ & $\beta$ & $t$ \\
\hline $\begin{array}{l}\text { Peer Attachment (Global) } \\
\text { General Model }\end{array}$ & .356 & .126 & .099 & $4.632^{*}$ & & \\
$\quad \begin{array}{l}\text { Behavioural Dysregulation } \\
\text { Cognitive Dysregulation }\end{array}$ & & & & & .076 & 0.614 \\
$\quad$ Affective Dysregulation & & & & & -.320 & $-3.320^{* *}$ \\
Communication & & & & -.221 & -1.793 \\
$\quad \begin{array}{l}\text { General Model } \\
\text { Behavioural Dysregulation }\end{array}$ & .461 & .212 & .188 & $8.616^{* * *}$ & & \\
$\quad$ Cognitive Dysregulation & & & & & .131 & 1.116 \\
Affective Dysregulation & & & & & -.465 & $-5.070^{* * *}$ \\
Trust & & & & & -.109 & -0.927 \\
$\quad \begin{array}{l}\text { General Model } \\
\text { Behavioural Dysregulation }\end{array}$ & .294 & .087 & .058 & $3.038^{*}$ & & \\
Cognitive Dysregulation & & & & & -.103 & 0.813 \\
Affective Dysregulation & & & & & -.271 & $-2.745^{* *}$ \\
\hline
\end{tabular}

Note. Standardized Coefficients $(\beta)$, t value $(\mathrm{t})$ and significance $(p):{ }^{\star} p<.05 ;{ }^{* *} p<.01 ;{ }^{* *} p<.001$

\section{DISCUSSION}

Given the significant role of peer relationships to the psychosocial development of adolescents, particularly to the ones that live in residential group homes, the present study sought to analyse how the emotional dysregulation of adolescents in residential care interfere with the attachment relationships they establish with their peers. To that end, the levels of emotional dysregulation and perception of peer attachment reported by the adolescents were firstly analysed.

Different from the expected, the reported levels of dysregulation among the adolescents in our sample were not high. Indeed, it is not uncommon for adolescents in residential care to present themselves with positive characteristics when narratively describing their own identity (Nobre-Lima, 2009). This is consistent with the idea of a false self that is created as a coping mechanism to help them deal with the adversities they face throughout their lives, and to obtain accept- 
ance from significant others (Harter, 1999). Results also showed that adolescents are more dysregulated in the affective domain than in the behavioural one. Since the affective development in early years precedes later forms of cognition and behaviour (Greenberg, 2006), the affective ambivalence that has characterized the development of adolescents in residential care might have prevented their emotional development from occurring properly, resulting in higher levels of affective dysregulation. Additionally, these adolescents are going through a developmental period that is by nature characterized by intense and reactive emotional experiences (Steinberg, 2005), which can contribute to enhance the levels of their affective dysregulation.

Affective and behavioural domains of regulation are known to be those that are most severely impacted due to early trauma experiences (Warner, Koomar, Lary, \& Cook, 2013). In our sample, behaviour dysregulation is not particularly high, but there is a strong positive correlation between these two types of dysregulation, suggesting that once one of them is affected, the other is more likely to emerge. Even so, none of these two types of psychological dysregulation better predicted the perception of peer attachment among the adolescents. It was cognitive dysregulation that best accounted for the variability of peer attachment. Curiously, cognitive dysregulation did not manifestly differentiate itself from the other forms of dysregulation, nor was correlated with them. Studies about brain development and emotional regulation during adolescence have already suggested that the cognitive component of regulation is the one that develops more slowly due to later maturation of executive functions (Ahmed, Bittencourt-Hewitt, \& Sebastian, 2015). Adolescents who went through experiences of adversity in their childhood tend to present compromised higher executive functions, which are consequently less used (Van der Kolk, 2005). Thus, the absence of cognitive mediation between affective and behavioural dysregulation becomes more evident, making adolescents more prone to easily disrupt in the onset of negative emotions. Moreover, because of their trajectories, these adolescents tend to use dissociation as a coping mechanism that helps them deal with the effects of adversity (Silberg, 2013). Once using dissociation, they can have a sense of cognitive control over their life.

It would be worth mentioning that items concerning cognitive dysregulation are the only ones that are inversely written, that is, they are formulated referring to the capacity of regulation. A tentative explanation is that this could have reinforced the need these adolescents have to hold some control over their lives, thus revealing lower levels of cognitive dysregulation than in fact may exist.

Regarding the relationship between emotional dysregulation and peer attachment, results show that cognitive dysregulation was the only dimension of emotional dys- 
regulation that showed a significant correlation with peer attachment - in general, in communication and in trust. Additionally, cognitive dysregulation was the one that best accounted for each one of these variables. This data is convergent with several theories on emotional regulation that describe the importance of cognition in the control of the behavioural expression of affection (Garnefski, Kraaij, \& Spinhoven, 2001; Thompson, 1994, 2011). In particular, studies with maltreated children have noted their difficulties to understand negative affection and to control it adaptively. These difficulties occur in a dynamic in which cognitive control acts as a partial mediator of the effects of maltreatment on the effectiveness of social interactions (Rogosch, Cicchetti, \& Aber, 1995). Since the development of intimate relationships with peers is moderated by the cognitive development of the adolescents (Berndt, 1982), it is understandable that the higher the cognitive dysregulation of adolescents in residential care, the less they perceive themselves as being able to trust and communicate with their peers, as well as being attached to them.

Concerning the adolescents' perception of attachment to peers, the adolescents reported having a good perception of this attachment, although presenting higher levels of trust and global attachment to peers when compared to communication. Both trust and communication showed a strong association with global attachment, even though the association is stronger with trust if we take into account Cohens' classification (2008). Allen (2008) explains that in the evolution of the attachment system in adolescence, attachment relationships rely less on physical proximity and more on mental representation of availability and safety. This is true not only for the relationship with parents in transformation, but also for the new relationships with friends. Earlier, when defining peer relationships as close relationships, Hazan and Shaver (1994) explained how they tend to transform. Although this relationship develops in the context of physical proximity, with time friends start to become predictable on their availability and responsiveness, contributing to an internalization of a sense of trust and security. For the developing adolescent, what becomes really important is to know that in times of need they can rely on a friend, thus decreasing proximity seeking. This might explain why, in our sample, trust showed a stronger association with global attachment than communication. Once in the context of residential care, relationships with peers are reinforced by the fact that they are the only ones that are truly freely chosen (Emond, 2014). When these relationships are good, the sense of trust is, probably, earlier achieved.

Although the present study focused on the predictive role of emotional dysregulation over peer attachment, previous studies have suggested that peer relationships may act as an important mediator and moderator of the influence of emotional dysregulation over aggressive behaviour (Röll, Koglin, \& Petermann, 2012). In the context of residential care, for example, practices that promote positive interactions 
with peers have demonstrated interesting results, with established improvements in the quality of peer relationships and the adolescents' self-concept (Bowers, Woods, Carlyon, \& Friman, 2000; James, 2011). Together, these studies and our results draw attention to the fact that both emotional dysregulation and peer attachment are interconnected, and therefore capable of influencing one another. This notion can be used as an important resource to guide future practices in the residential care context.

The greatest limitation of our study concerns the sample size, which is in part related to the difficulty of access to the group homes. Even though it can be considered acceptable given the characteristics of the population in study, it restricts a broader generalization of the results. Also, the discrepancy between boys and girls in the sample does not allow more thorough analyses in order to enlighten particularities of the relationship between these variables.

\section{CONCLUSIONS}

The present study evidenced the predictive role of cognitive dysregulation to the perception of attachment to peers of adolescents in residential care. Considering that a sense of trust and connection to others is so urgent and fundamental in a context of out-of-home care, this result, albeit modest, stresses the importance of providing adolescents in residential care with regulatory resources that they can use as coping mechanisms to deal with interpersonal relationships. The promotion of individual regulation competences in both cognitive and emotional domains may trigger not only a sense of self-control but also a more pro-social behaviour that in turn can lead to more empathetic and intimate relationships.

When speaking about endowing adolescents in residential care with regulatory skills and promoting their interpersonal relationships, we undoubtedly talk about the quality of care in the residential settings. To promote new secure attachments in adolescents with insecure attachments in their past can be a challenge but does not have to be impossible. We may take the example of what happens in foster care to infer that it is possible (Joseph, O’Connor, Briskman, Maughan, \& Scott, 2014). The identification of the practices undertaken in residential care settings that better promote emotional regulation and new attachment relationships is, for sure, an investment in more adaptive developmental pathways of the cared adolescents.

In future studies it would be interesting to design developmentally informed intervention strategies and to test its impact on the promotion of emotion regulation competencies and, ultimately, on attachment to significant others in the residential 
care context. With an enlarged and more gender balanced sample, it would be interesting to study potential differences in this same relationship according to gender.

\section{REFERENCES}

Ahmed, S. P., Bittencourt-Hewitt, A., \& Sebastian, C. L. (2015). Neurocognitive bases of emotion regulation development in adolescence. Developmental Cognitive Neuroscience, 15, 11-25. doi: 10.1016/j.dcn.2015.07.006

Allen, J. (2008). The attachment system in adolescence. In J. Cassidy \& P. Shaver (Eds.), Handbook of attachment: Theory, research and clinical applications (p. 419-435). NY: The Guilford Press

Armsden, G., \& Greenberg, M. (1987). The inventory of parent and peer attachment: Individual differences and their relationship to psychological well-being in adolescence. Journal of Youth and Adolescence, 16(5), 427-454. doi: 10.1007/BF02202939

Avery, R., \& Freundlich, M. (2009). You're all grown up now: Termination of foster care support at age 18. Journal of Adolescence, 32(2), 247-257. doi: 10.1016/j.adolescence.2008.03.009

Balluerka, N., Gorostiaga, A., Alonso-Arbiol, I., \& Aritzeta, A. (2016). Peer attachment and class emotional intelligence as predictors of adolescents' psychological well-being: A multilevel approach. Journal of Adolescence, 53, 1-9. doi: 10.1016/j.adolescence.2016.08.009

Barn, R. (2010). Care leavers and social capital: Understanding and negotiating racial and ethnic identity. Ethnic and Racial Studies, 33(5), 832-850. doi: 10.1080/01419870903318896

Barter, C. (2003). Young people in residential care talk about peer violence. Scottish Journal of Residential Child Care, 2(2), 39-50. Retrieved from http://www.sircc.org.uk/sites/default/ files/Peer_Violence.pdf

Barter, C. (2008). Prioritizing young people's concerns in residential care: Responding to peer violence. In A. Kendrick (Ed.), Residential child care: Prospects and challenges (pp. 137-151). London: Jessica Kingsley.

Berndt, T. J. (1982). The features and effects of friendship in early adolescence. Child Development, 53(6), 1447-1460. doi: 10.2307/1130071

Bolger, K. E., Patterson, C. J., \& Kupersmidt, J. B. (1998). Peer relationships and self-esteem among children who have been maltreated. Child Development, 69(4), 1171-1197. doi: 10.1111/j.14678624.1998.tb06166.x

Boruah, A. (2016). Positive impacts of peer pressure: A systematic review. Indian Journal of Positive Psychology, 7(1), 127-130.

Bowers, F., Woods, D., Carlyon, W., \& Friman, P. (2000). Using positive peer reporting to improve the social interactions and acceptance of socially isolated adolescents in residential care: A systematic replication. Journal of Applied Behavior Analysis, 33(2), 239-242. doi: 10.1901/jaba.2000.33-239

Cicchetti, D., \& Toth, S. L. (2005). Child maltreatment. Annual Review of Clinical Psychology, 1, 409438. doi: 10.1146/annurev.clinpsy.1.102803.144029

Cohen, B. (2008). Explaining psychological statistics. New Jersey: Hoboken.

Cole, P. M., Martin, S. E., \& Dennis, T. A. (2004). Emotion regulation as a scientific construct: Methodological challenges and directions for child development research. Child Development, 75(2), 317-333. doi: 10.1111/j.1467-8624.2004.00673.x 
Cook, E. C., Buehler, C., \& Henson, R. (2009). Parents and peers as social influences to deter antisocial behavior. Journal of Youth and Adolescence, 38(9), 1240-1252. doi: 10.1007/s10964-008-9348-x

Cook, A., Spinazzola, J., Ford, J., Lanktree, C., Blaustein, M., Cloitre, M., ... Van der Kolk, B. (2005). Complex trauma in children and adolescents. Psychiatric Annals, 35(5), 390-398. Retrieved from https://nursebuddha.files.wordpress.com/2011/12/complex-trauma-in-children.pdf

Crittenden, P. M. (1992). Quality of attachment in the preschool years. Development and Psychopathology, 4(2), 209-241. doi: 10.1017/S0954579400000110

Emond, R. (2003). Putting the care into residential care: The role of young people. Journal of Social Work, 3(3), 321-337. doi: 10.1177/146801730333004

Emond, R. (2014). Longing to belong: Children in residential care and their experiences of peer relationships at school and in children's home. Child and Family Social Work, 19(2), 194-202. doi:10.1111/j.1365-2206.2012.00893.x

Garnefski, N., Kraaij, V., \& Spinhoven, P. (2001). Negative life events, cognitive emotion regulation and emotional problems. Personality and Individual Differences, 30, 1311-1327. doi: 10.1016/ S0191-8869(00)00113-6

Gorrese, A., \& Ruggieri, R. (2012). Peer attachment: A meta-analytic review of gender and age differences and associations with parent attachment. Journal of Youth and Adolescence, 41, 650-672. doi: $10.1007 /$ s10964-012-9759-6

Greenberg, M. T. (2006). Promoting resilience in children and youth. Annals of the New York Academy of Sciences, 1094, 139-150. doi: 10.1196/annals.1376.013

Greger, H. K., Myhre, A. K., Lydersen, S., \& Josefiak, T. (2015). Previous maltreatment and present mental health in a high-risk adolescent population. Child Abuse \& Neglect, 45, 122-134. doi: 10.1016/j.chiabu.2015.05.003

Greger, H. K., Myhre, A. K., Lydersen, S., \& Jozefiak, T. (2016). Child maltreatment and quality of life: A study of adolescents in residential care. Health and Quality of Life Outcomes, 14(74), 1-17. doi: 10.1186/s12955-016-0479-6

Gwynn, C., Meyer, R., \& Schaefer, C. (1993). The influence of the peer culture in residential treatment. In C. Schaefer \& A. Swanson (Eds.), Children in residential care: Critical issues in treatment (2a ed., pp. 104-133). Northvale, N.J.: Jason Aronson Inc.

Hair, J. F., Black, W. C., Babin, B. J., \& Anderson, R. E. (2009). Multivariate data analysis (7 $7^{\text {th }}$ ed.). NJ: Prentice-Hall.

Harter, S. (1999). The construction of the self: A developmental perspective. New York: The Guilford Press.

Hazan, C., \& Shaver, P. (1994). Attachment as an organizational framework for research on close relationships. Psychological Inquiry, 5(1), 1-22. doi: 10.1207/s15327965pli0501_1

Inácio, S. (2015). Indicadores de resiliência em adolescentes institucionalizados: O papel da vinculação aos pares, professores e funcionários da instituição (Unpublished master dissertation). Instituto Superior Miguel Torga, Coimbra.

James, S. (2011). What works in group care? A structured review of treatment models for group homes and residential care. Children and Youth Services Review, 33(2), 308-321. doi: 10.1016/j. childyouth.2010.09.014

Jongenelen, I., Carvalho, M., Mendes, T., \& Soares, I. (2009). Vinculação na adolescência [Attachment in adolescence]. In I. Soares (Coord.), Relações de vinculação ao longo do desenvolvimento: Teoria e avaliação (2a ed., pp. 99-120). Braga: Psiquilíbrios.

Joseph, M. A., O'Connor; T. G., Briskman, J. A., Maughan, B., \& Scott, S. (2014). The formation of secure new attachments by children who were maltreated: An observational study of adolescents in foster care. Development and Psychopathology, 26, 67-80. doi:10.1017/S0954579413000540 
Kim, J., \& Cicchetti, D. (2010). Longitudinal pathways linking child maltreatment, emotion regulation, peer relations and psychopathology. Journal of Child Psychology and Psychiatry, 51(6), 706-716. doi: 10.1111/j.1469-7610.2009.02202.x

Kline, R. B. (2011). Principles and practice of structural equation modeling ( $3^{\text {rd }}$ ed.). New York: The Guilford Press.

Laible, D. (2007). Attachment with parents and peers in late adolescence: Links with emotional competence and social behavior. Personality and Individual Differences, 43(5), 1185-1197. doi:10.1016/j.paid.2007.03.010

Lazarus, R. (2006). Emotions and interpersonal relationships: Toward a person-centered conceptualization of emotions and coping. Journal of Personality, 74(1), 9-46. doi: 10.1111/j.14676494.2005.00368.x

Manful, E., \& Badu-Nyarko, S. (2014). Exploring the usefulness of social capital concept for improving services for vulnerable children and orphans in a public residential care institution in Ghana. American International Journal of Social Science, 3(3), 83-98. Retrieved from http:// www.aijssnet.com/journals/Vol_3_No_3_May_2014/8.pdf

Meeus, W., Iedema, J., Maassen, G., \& Engels, R. (2005). Separation-individuation revisited: On the interplay of parent-adolescent relations, identity and emotional adjustment in adolescence. Journal of Adolescence, 28, 89-106. doi: 10.1016/j.adolescence.2004.07.003

Mezzich, A., Tarter, R., Giancola, P., \& Kirisci, L. (2001). The dysregulation inventory: A new scale to access the risk for substance use disorder. Journal of Child and Adolescent Substance Abuse, 10(4), 35-43. doi: 10.1300/J029v10n04_04

Monks, C. P., Smith, P. K., Naylor, P., Ireland, J. L., \& Coyne, I. (2009). Bullying in different contexts: Commonalities, differences and the role of theory. Aggression and Violent Behavior, 14(2), 146-156. doi: 10.1016/j.avb.2009.01.004

Morgan, R. (2009). Life in children's homes: A report of children's experience. Manchester: Ofsted.

Morris, A. S., Silk, J. S., Steinberg, L., Myers, S. S., \& Robinson, L. R. (2007). The role of the family context in the development of emotion regulation. Social Development, 16(2), 361-388. doi: 10.1111/j.1467-9507.2007.00389.x

Mota, C. P., \& Matos, P. M. (2010). Adolescentes institucionalizados: O papel das figuras significativas na predição da assertividade, empatia e autocontrolo [Institutionalized adolescents: The role of significant figures in the prediction of assertiveness, empathy and self-control]. Análise Psicológica, 28(2), 245-254. doi: 10.14417/ap.278

Mota, C. P., \& Matos, P. M. (2015). Adolescents in institutional care: Significant adults, resilience, and well-being. Child and Youth Care Forum, 44(2), 209-224. doi: 10.1007/s10566-014-9278-6

Motta, C., Rijo, D., Sousa, B., Pereira, M., \& Correia, L. (n.d.). The Abbreviated Dysregulation Inventory: Dimensionality and psychometric properties. Manuscript in preparation.

Neves, L. (1995). Suporte emocional na adolescência: A relação com os pais e com os amigos em momentos de transição escolar (Unpublished master dissertation). University of Coimbra, Coimbra.

Neves, L., Soares, I., \& Silva, M. C. (1999). Inventário da Vinculação na Adolescência - I.P.P.A [The Attachment Inventory in Adolescence - I.P.P.A.]. In M. Simões, M. Gonçalves, \& L. Almeida (Eds.), Testes e provas psicológicas em Portugal (Vol. 2, pp. 37-48). Braga: Sistemas Humanos e Organizacionais, Lda.

Nobre-Lima, L. (2009). Estórias e projetos de vida de adolescentes institucionalizados (Unpublished doctoral thesis). University of Coimbra, Coimbra. 
Petiz, M. V. (2011). Contributo para a validação da Escala de Conflitos Entre Pares: Estudos psicométricos e relação com medo da avaliação negativa e esquemas nucleares (Unpublished master dissertation). University of Coimbra, Coimbra.

Rogosch, F. A., Cicchetti, D., \& Aber, J. L. (1995). The role of child maltreatment in early deviations in cognitive and affective processing abilities and later peer relationship problems. Development and Psychopathology, 7(4), 591-609. doi: 10.1017/S0954579400006738

Röll, J., Koglin, U., \& Petermann, F. (2012). Emotion regulation and childhood aggression: Longitudinal associations. Child Psychiatry and Human Development, 43(6), 909-923. doi: 10.1007/ s10578-012-0303-4

Sasikala, S., \& Cecil, N. (2016). Parental bonding, peer attachment and psychological well-being among adolescents: A mediation analysis. Journal of Psychosocial Research, 11(1), 21-31.

Schore, A. N. (2001). The effects of early relational trauma on right brain development, affect regulation, and infant mental health. Infant Mental Health Journal, 22(1-2), 201-269. doi: 10.1002/1097-0355(200101/04)22:1<201::AID-IMHJ8>3.0.CO;2-9

Schore, A. N. (2003). Affect dysregulation and disorders of the self (1 $1^{\text {st }}$ ed., Vol. 1, pp. 178-233). New York: W. W. Norton.

Shaw, J. (2014). Why do young people offend in children's homes? Research, theory and practice. British Journal of Social Work, 44(7), 1823-1839. doi: 10.1093/bjsw/bct047

Shaw, J., \& Frost, N. (2013). Young people and the care experience: Research, policy and practice. New York: Routledge.

Silberg, J. L. (2013). The child survivor: Healing developmental trauma and dissociation (pp. 1-13). New York: Routledge.

Soares, I. (1996). Representação da vinculação na idade adulta e na adolescência: Estudo intergeracional mãe-filho(a) [Attachment representation in adulthood and in adolescence: A mother-child intergenerational study]. Braga: Editora da Universidade do Minho.

Steinberg, L. (2005). Cognitive and affective development in adolescence. Trends in Cognitive Sciences, 9(2), 69-74. doi:10.1016/j.tics.2004.12.005

Steinberg, L., \& Silk, J. S. (2002). Parenting adolescents. In M. H. Bornstein (Ed.), Handbook of parenting: Vol 1 - Children and parenting (pp.103-133). Mahwah, NJ: Lawrence Erlbaum Associates.

Thompson, R. A. (1994). Emotion regulation: A theme in search of definition. Monographs of the Society for Research in Child Development), 59(2-3), p. 25-52.

Thompson, R. A. (2011). Emotion and emotion regulation: Two sides of the developing coin. Emotion Review, 3(1), 53-61. doi: 10.1177/1754073910380969

Tomé, G., Gaspar de Matos, M., Camacho, I., Simões, C., \& Diniz, J. A. (2012). Portuguese adolescents: The importance of parents and peer groups in positive health. Journal of Psychology, 15(3), 1315-1324. doi: 10.5209/rev_SJOP.2012.v15.n3.39417

Trickett, P. K., Negriff, S., Ji, J., \& Peckins, M. (2011). Child maltreatment and adolescent development. Journal of Research on Adolescence, 21(1), 3-20. doi:10.1111/j.1532-7795-2010-00711.x

Van der Kolk, B. A. (2005). Developmental trauma disorder: Toward a rational diagnosis for children with complex trauma histories. Psychiatric Annals, 35(5), 401-408.

Warner, E., Koomar, J., Lary, B., \& Cook, A. (2013). Can the body change the score? Application of sensory modulation principles in the treatment of traumatized adolescents in residential care. Journal of Family Violence, 28(7), 729-738. doi: 10.1007/s10896-013-9535-8 